\title{
Outcome of EGFR inhibitors treatment in advanced NSCLC patients, not enrolled in clinical trials
}

\author{
M. MENCOBONI ${ }^{1, *}$, R. A. FILIBERTI ${ }^{2}$, P. TAVEGGIA ${ }^{1}$, A. BRUZZONE ${ }^{1}$, A. GARUTI $^{3}$, L. DEL CORSO ${ }^{3}$, E. GINOCCHIO ${ }^{1}$, A. BRIANTI ${ }^{4}$, C. SIMONASSI ${ }^{4}$, \\ P. ZUCALI ${ }^{5}$ \\ ${ }^{1}$ Oncology Unit, Villa Scassi Hospital ASL 3 Genovese, Corso Scassi 1, 16149 Genova, Italy; ${ }^{2}$ Clinical Epidemiology, ${ }^{3}$ Internal Medicine Department, \\ University of Genova, IRCCS AOU San Martino - IST, Largo Rosanna Benzi, 10, 16132 Genova Italy; ${ }^{4}$ Pneumology Unit, Villa Scassi Hospital \\ ASL 3 Genovese, Corso Scassi 1, 16149 Genova Italy; ${ }^{5}$ Paolo Zucali, Istituto Clinico Humanitas, Via Manzoni 56, 20089 Rozzano (MI) Italy
}

${ }^{*}$ Correspondence: manlio.mencoboni@fastwebnet.it

Received March 23, 2016 / Accepted August 12, 2016

\begin{abstract}
Epidermal growth factor receptor tyrosine kinase inhibitors (EGFR-TKIs) have become a treatment after first-line chemotherapy in patients with advanced NSCLC. We assessed the predictive and prognostic role of EGFR and Kras mutations in NSCLC patients treated with TKIs after progression, not included in clinical trials. Gefitinib $250 \mathrm{mg}$ or Erlotinib $150 \mathrm{mg}$ per os were administered to 70 patients. Radiological assessment was performed every six weeks. EGFR and Kras mutations were found in $21.4 \%$ and $24.3 \%$ of patients, respectively. At multivariate analysis, Kras mutation was positively associated with progression-free survival (PFS; $\mathrm{HR}=0.71,95 \% \mathrm{CI}$ : 0.53-0.96; $\mathrm{p}=0.027)$ and, less clearly, with response $(\mathrm{OR}=1.84,95 \% \mathrm{CI}$ : 0.98-3.45; $\mathrm{p}=0.057)$ and survival (HR=0.74, 95\% CI:0.54-1.02; $\mathrm{p}=0.066)$. EGFR mutation influenced positively PFS (HR=0.69, 95\% CI: 0.47-1.02; $\mathrm{p}=0.06$ ), but not survival. In conclusion, in our unselected patients mutation of Kras correlated with a better outcome. The small number of patients may explain some discrepancies with data in literature.
\end{abstract}

Key words: EGFR, Kras, Erlotinib, Gefitinib, mutation, non-small cell lung cancer

Most patients with non-small-cell lung cancer (NSCLC) present with advanced disease. Current treatment paradigms are chemotherapies and targeted therapies. As patient responses to these therapies vary, predictive biomarkers may be an important facet of a patient's diagnostic workup in personalized medicine: there is accumulating evidence that they may entail prognostication and prediction of therapeutic response. Biomarkers for the selection of patients with NSCLC most likely to benefit from epidermal growth factor receptor tyrosine kinase inhibitors (EGFR-TKIs), such as Gefitinib and Erlotinib, include mutations and single-nucleotide polymorphisms of the EGFR gene and mutations on the Kras gene [1,2]. EGFR-TKI treatment in metastatic NSCLC patients significantly improves progression-free survival (PFS) with acceptable toxicities [3,4], being effective and tolerated also in elderly patients with EGFR mutations [5]. Especially, NSCLC with exon 19 deletions had longer median PFS and overall survival (OS) than NSCLC with other mutations such as exon 21 L858R substitution $[3,6]$, while the wild-type EGFR was associated with poorer outcomes, irrespective of Kras status [3].
The significance of the Kras mutant status on treatment response in NSCLC patients remains controversial and so far there is insufficient evidence to determine the association between KRAS status and tumor progression or survival [7]. Reviews of several studies suggested that Kras mutations could be used as a potential negative predictor of clinical benefit from EGFR-TKIs in unselected advanced NSCLC patients, but they are of limited value when EGFR status is considered $[8,9]$. Similarly, other papers showed that in lung cancer patients, in contrast with colorectal cancer, patients with mutant tumors did not benefit from adjuvant chemotherapy, and their disease did not respond to EGFR inhibitors [10]. Despite some conflicting findings it is clear that Kras mutations are characterized by a complex biology involving the interaction between different Kras amino acid substitutions, various growth factor pathways, and several tumor suppressor genes [10-12].

Anyway, in recent years, the management of lung cancer has moved towards molecular-guided treatment.

We studied a consecutive series of NSCLC patients not included in clinical trials, treated between 2007 and 2009 in 2 
Italian Hospitals. These patients received EGFR-TKI inhibitors as second or third line therapy, as the approval of these drugs in a first line setting was not available at the time of the study. We correlated PFS, OS and objective response rate (ORR) to mutational status of EGFR and Kras and to some clinical features of patients.

\section{Patients and methods}

Seventy NSCLC metastatic patients were included in the study. They received Gefitinib $250 \mathrm{mg}$ or Erlotinib $150 \mathrm{mg}$ per os after first or second line or third line chemotherapy when progression occurred. Tumor response was assessed according

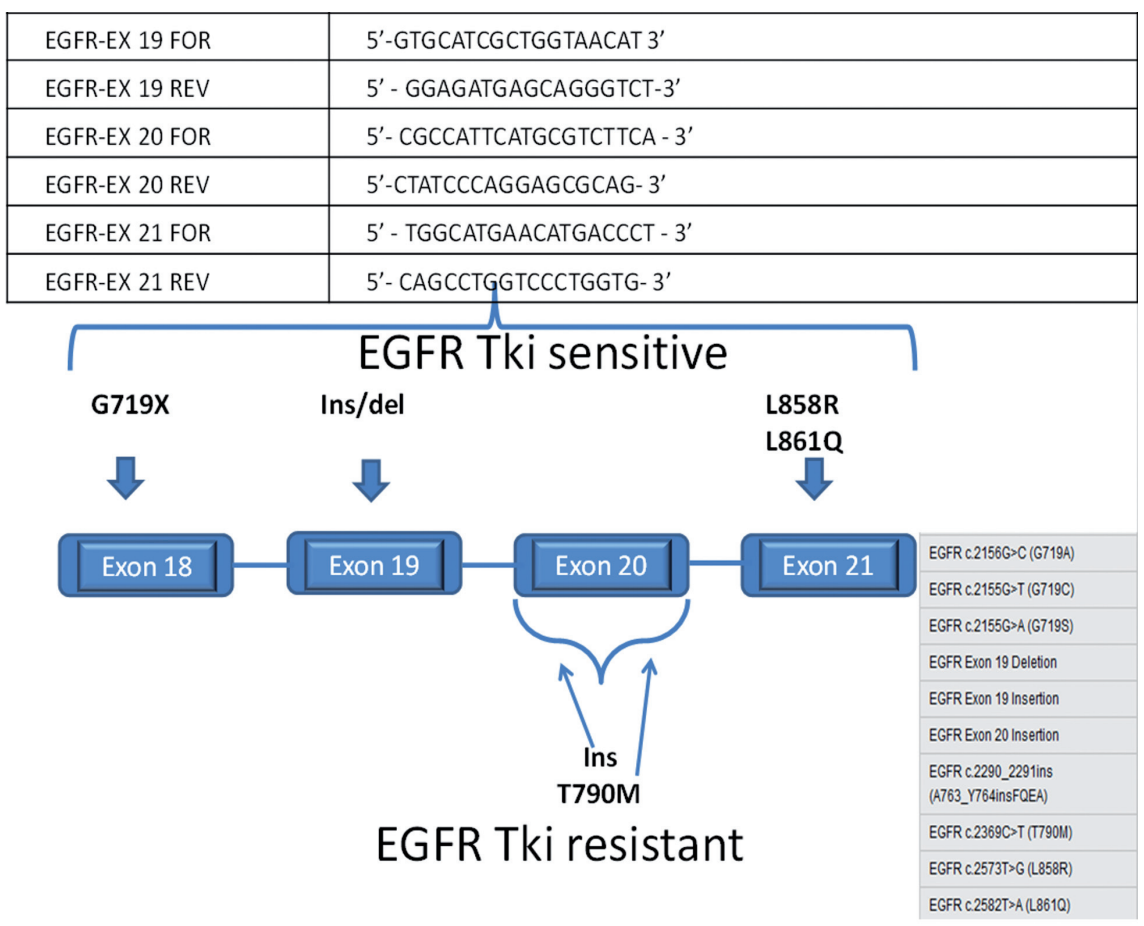

\begin{tabular}{|c|c|}
\hline Kras EX 2 FOR & 5'-AAGGCCTGCTGAAAATGACTG-3' \\
\hline Kras EX 2 REV & 5'-CAAAGAATGGTCCTGCACCAG-3' \\
\hline
\end{tabular}

Kras

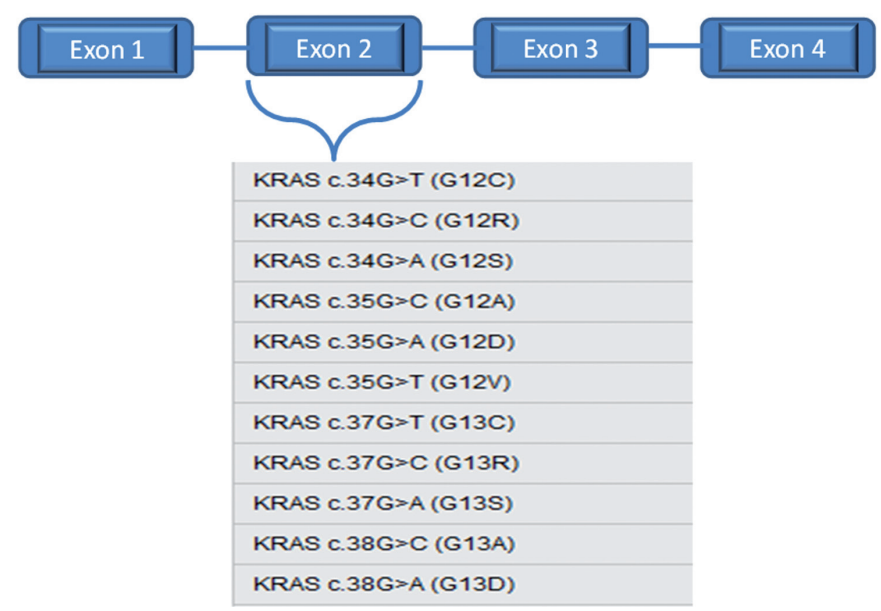


to the Response Evaluation Criteria in Solid Tumors (RECIST): complete response (CR) was complete disappearance of all objective evidence of disease; partial response (PR) was $\geq 30 \%$ reduction in size (products of the two longest perpendicular diameters) of measurable lesions without any new lesion; progressive disease (PD) was $\geq 20 \%$ increase in size of known lesions or appearance of new lesions; stable disease (SD) was all other situations [13]. Radiological assessment was performed with CT scan every six weeks. Patients with a radiological objective response with either RECIST CR or PR or SD were considered as responders. All patients received TKI and then were tested for EGFR and Kras.

DNA extraction, EGFR and Kras mutation analysis. DNA was extracted from FFPE tissue samples using QIAamp DNA FFPE Tessue Kit (Qiagen, Hamburg, Germany). Briefly, 3 sections $(8 \mu \mathrm{m})$ were cut from FFPE tissue sample. When it was necessary we performed a macro-dissection following the instructions anatomopathologist to obtain almost 50\% of tumoral cells. Tissue sections were incubated in Buffer ATL (Qiagen) and proteinase $\mathrm{K}$ at $56^{\circ} \mathrm{C}$ until the tissue was completely lysed (1-3 hours), and then at $90^{\circ} \mathrm{C}$ (1 hour) to reverse formalin crosslinking. The DNA was extracted using manufacturer's protocol.

Sanger sequencing was used to analyse EGFR exons 18, 19, 20, and 21 and Kras exon 2 (Figure 1). DNA was amplified by PCR (Mastercycler, Eppendorf) in $25 \mu$ reactions containing $40 \mathrm{ng}$ of template DNA, 12.5 $\mathrm{l}$ AMPLITAQ GOLD 360 (Life Technologies) and $0.5 \mu \mathrm{M}$ of forward and reverse primers. PCR conditions for EGFR amplification were $95^{\circ} \mathrm{C} 10 \mathrm{~min}$, $45 \mathrm{X}\left(94^{\circ} \mathrm{C} 45 \mathrm{~s}, 65^{\circ} \mathrm{C} 45 \mathrm{~s}, 72^{\circ} \mathrm{C} 45 \mathrm{~s}\right)$ and $72^{\circ} \mathrm{C}$ for $7 \mathrm{~min}$. PCR conditions for Kras amplification were $95^{\circ} \mathrm{C} 10 \mathrm{~min}, 45 \mathrm{X}\left(95^{\circ} \mathrm{C}\right.$ $30 \mathrm{~s}, 58^{\circ} \mathrm{C} 30 \mathrm{~s}, 72^{\circ} \mathrm{C} 40 \mathrm{~s}$ ) and $72^{\circ} \mathrm{C}$ for $7 \mathrm{~min}$. Amplification of a single PCR product of the expected size was electroforetically confirmed on a $2 \%$ agarose gel by ethidium bromide staining and UV-light. The PCR product was purified by removal of residual primers and nucleotides in reactions containing $10 \mu \mathrm{l}$ PCR product and $2 \mu \mathrm{l}$ illustra ExoStar 1-Step. The PCR product was then used as a template for sequencing reactions in both forward and reverse directions in $20 \mu \mathrm{l}$ reactions containing; $0.5 \mu \mathrm{M}$ forward and reverse primer, $1 \mu \mathrm{l}$ BigDye Terminator (Applied Biosystems), $2 \mu$ BigDye Terminator Buffer (Applied Biosystems) and 2-4 $\mu \mathrm{l}$ purified PCR product. The sequencing conditions were $25 \mathrm{X}\left(96^{\circ} \mathrm{C} 10 \mathrm{~s}, 50^{\circ} \mathrm{C} 5 \mathrm{~s}, 60^{\circ} \mathrm{C} 4 \mathrm{~min}\right)$. The amplicon was then precipitated by using Performa ${ }^{\circ}$ DTR Ultra 96-Well Plate Kit (EdgeBio ). DNA was analysed on an ABI 3130 Genetic Analyzer (Applied Biosystems).

Statistical analysis. Continuous variables distribution was reported as median (range). The study population was categorized according to the median of the age distribution (i.e., <=61 and >61 years), histology (adenocarcinoma and others), PS ECOG (0-1 and 2), smoking status as never smoker and smoker (former- and current smoker). EGFR and Kras genotypes were classified as wild type or mutated. EGFR was considered mutated when at least one mutation in 18-21 exons was present. The relationship between categorical variables was examined by means of the chi-square test. Odds Ratios (OR) and the corresponding $95 \%$ confidence intervals $(95 \% \mathrm{CI})$ for Kras and EGFR status (mutation vs wild type), gender (female vs male) and smoking habits (smoker vs never smoker) were computed to predict therapy response using multiple logistic regression analysis. The Kaplan-Meier method was applied in univariate analysis to estimate survival and PFS probabilities and the log-rank test was carried out to assess heterogeneity within each prognostic factor. Multivariate analyses were conducted using Cox regression model including terms for EGFR and Kras status (mutation vs wild type) and for the other variables that reached a $\mathrm{p}<=0.2$ in univariate analysis. PFS was defined as the time from TKIs initiation until documented disease progression or death. OS was defined as the time from TKI initiation until death from any cause or last follow-up. Statistical calculations were performed using the SPSS statistical package version 20. For all comparisons, a two sided $p$ value of $<0.05$ was considered as statistically significant.

\section{Results}

Patients characteristics at enrollment were as follows: median age 62.6 years (range $37-80$ years), 48 males, and 53 adenocarcinoma histological subtype. Fifty-nine patients $(84.3 \%)$ were smokers (Table 1$)$. All patients were tested for

Table 1. NSCLC patients characteristics.

\begin{tabular}{|c|c|c|}
\hline & No. of patients (70) & $\%$ \\
\hline \multicolumn{3}{|l|}{ Gender } \\
\hline Male & 48 & 68.6 \\
\hline Female & 22 & 31.4 \\
\hline Age, median (range) & $62.6(37-80)$ & \\
\hline \multicolumn{3}{|l|}{ Histology } \\
\hline Adenocarcinoma & 53 & 75.7 \\
\hline Squamous & 13 & 18.6 \\
\hline NSCLC unspecified & 4 & 5.7 \\
\hline \multicolumn{3}{|l|}{ PS ECOG } \\
\hline $0-1$ & 56 & 80.0 \\
\hline 2 & 14 & 20.0 \\
\hline \multicolumn{3}{|l|}{ Smoking status } \\
\hline Never smoker & 11 & 15.7 \\
\hline Smoker & 59 & 84.3 \\
\hline \multicolumn{3}{|l|}{ Best response } \\
\hline Progression & 40 & 57.1 \\
\hline Stable disease & 26 & 37.2 \\
\hline Response & 4 & 5.7 \\
\hline \multicolumn{3}{|l|}{ EGFR genotype } \\
\hline Wild type & 55 & 78.6 \\
\hline Mutated & 15 & 21.4 \\
\hline \multicolumn{3}{|l|}{ Kras genotype } \\
\hline Wild type & 53 & 75.7 \\
\hline Mutated & 17 & 24.3 \\
\hline
\end{tabular}


EGFR exons 19 and 20, while exon 18 and exon 21 were tested in 22 and 52 of them, respectively. Fourteen patients (20\%) were positive for at least one EGFR mutation ( 1 in exon 18, 4 in exon 19, 8 in exon 20 and 1 in exon 21). A mutation in both exon 20 and 21 was detected in one case. A mutation was found in $27.3 \%$ of females and in $18.8 \%$ of males $(\mathrm{p}=0.5)$ and in $15.3 \%$ of smokers versus 54.5 of never smokers $(p=0.01)$. No differences were observed with regard to histology. A Kras mutation was found in 17 (24.3\%) patients (31.8\% of females and $20.8 \%$ of males, $\mathrm{p}=0.4)$. Never smokers $(\mathrm{n}=11)$ were all mutation negative, while mutation was found in $28.8 \%$ of smokers $(\mathrm{p}=0.055)$. According to histology, mutation was found in $32.1 \%$ of adenocarcinomas, but not in the other or not specified histotypes $(\mathrm{p}=0.007)$. EGFR and Kras mutations were mutually exclusive.

\section{A}

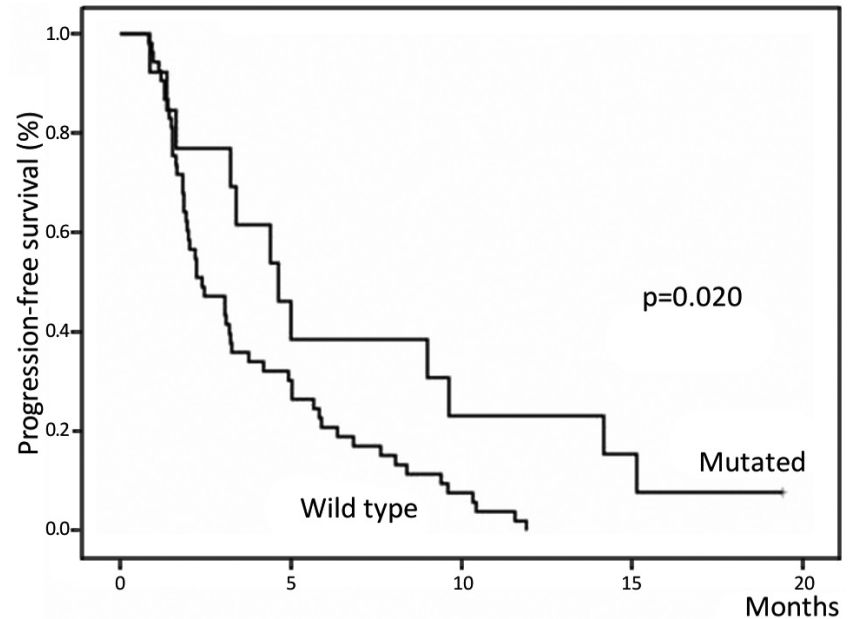

B

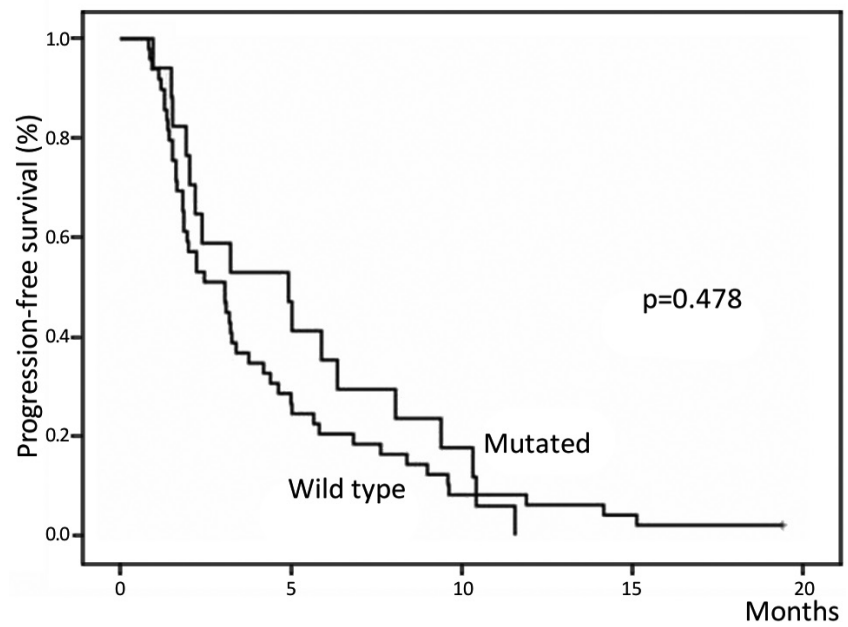

Figure 2. Progression-free survival of NSCLC patients according to EGFR (A) and Kras (B) status
Patients underwent TKI therapy after a median period of 14.0 months from diagnosis (range 0.7-70.7 months). On average, patients had received 1 prior line of chemotherapy (range $1-4)$. ECOG PS was $0-1$ in $56(80.0 \%)$ patients.

Response to therapy. Forty-four patients (57.1\%) had PD as their best response. Only 4 patients (all adenocarcinoma, median age 56.6 years) achieved a PR. Gender, age, histology and PS were not associated with the probability of response, while an objective response was achieved in $72.7 \%$ of never smokers versus $37.3 \%$ of smokers $(p=0.045)$. Patients with at least an EGFR mutation had a response rate of $40 \%$, similar to that of patients with wild type EGFR (43.6\%). ORR was higher in patients with Kras mutation respect to wild type patients ( $58.8 \%$ vs $37.7 \%)$, but the difference was not significant $(\mathrm{p}=0.2)$ (Table 2). The response rate was $36.8 \%$ in patients with both Kras and EGFR wild type tumors. According to the EGFR genotype, response was obtained in the only one patient with mutated exon 18 (vs $23.8 \%$ of response in wild type), in $75 \%$ of mutated exon 19 (40.9\% in wild type) and in $25 \%$ of the mutated exon 20 cases ( $45.9 \%$ in wild type). No response was obtained in the case with mutation in exon 21 ( $50 \%$ in wild type) and in the case of mutation of both exon 20 and 21.

Logistic regression analysis confirmed the inverse association between objective radiological response and smoke, showing an $\mathrm{OR}=0.33$ (95\%CI: 0.13-0.85, $\mathrm{p}=0.02$ ). In addition, a non statistically significant association was found with

Table 2. Individual characteristics and radiological objective response in NSCLC patients

\begin{tabular}{|c|c|c|c|}
\hline & $\begin{array}{c}\text { NO response } \\
\mathrm{N}(\%)^{*}\end{array}$ & $\begin{array}{c}\text { Response } \\
\mathrm{N}(\%)^{*}\end{array}$ & $\mathrm{p}$ \\
\hline Gender & & & 0.203 \\
\hline Male & $30(62.5)$ & $18(37.5)$ & \\
\hline Female & $10(45.5)$ & $12(54.5)$ & \\
\hline Age (years) & & & 0.338 \\
\hline$\leq 61$ & $14(50.0)$ & $14(50.0)$ & \\
\hline$>61$ & $26(61.9)$ & $16(38.1)$ & \\
\hline Histology & & & 1.000 \\
\hline Adenocarcinoma & $29(54.7)$ & $24(45.3)$ & \\
\hline Squamous cell ca & $7(53.8)$ & $6(46.2)$ & \\
\hline PS & & & 0.562 \\
\hline $0-1$ & $33(58.9)$ & $23(41.1)$ & \\
\hline 2 & $7(50.0)$ & $7(50.0)$ & \\
\hline Smoking status & & & 0.045 \\
\hline Never smoker & $3(27.3)$ & $8(72.7)$ & \\
\hline Smoker & $37(62.7)$ & $22(37.3)$ & \\
\hline EGFR genotype & & & 1.000 \\
\hline Wild type & $31(56.4)$ & $24(43.6)$ & \\
\hline Mutated & $9(60.0)$ & $6(40.0)$ & \\
\hline Kras genotype & & & 0.163 \\
\hline Wild type & $33(62.3)$ & $20(37.7)$ & \\
\hline Mutated & $7(41.2)$ & $10(58.8)$ & \\
\hline Overall & $40(57.1)$ & $30(42.9)$ & \\
\hline
\end{tabular}


Kras mutation $(\mathrm{OR}=1.84,95 \% \mathrm{CI}: 0.98-3.45 ; \mathrm{p}=0.057)($ data not shown).

Progression-free survival. Overall, median PFS was 3.1 months (95\% CI: 2.1-4.1 months) (Table 3). A statistically significant prolonged PFS was observed in female (median 4.6 vs 2.2 months for males, $\mathrm{p}=0.04$ ), never smoker ( 5.8 months vs 2.2 months for smokers, $\mathrm{p}=0.011$ ) and EGFR mutated status (median 4.6 months vs 2.4 months for wild type genotype, $\mathrm{p}=0.02$ ). Kras mutation was not associated with PFS (median 4.9 months for mutated vs 3.1 months for wild type genotype, $\mathrm{p}=0.5$ ). Figures $2 \mathrm{~A}-\mathrm{B}$ show PFS according to EGFR and Kras status, respectively. Median PFS was 2.0 months (95\% CI: 1.52.5 months) in patients with both Kras and EGFR wild type tumors. According to the EGFR genotypes, the patient with mutation in exon 18 had a PFS of 15.1 months. Median PFS was 4.6 months (95\% CI: $0.5-10.3$ months) in patients with mutation in exon 19 and 4.4 months (95\%CI:1.8-7.0 months) in mutated exon 20 cases. The patient with mutation in exon 21 and the case of mutation of both exon 20 and 21 had a PFS of 26 days and 3.5 months, respectively.

Multivariate Cox regression analysis for PFS included EGFR and Kras status (mutation vs wild type), gender (female vs male), PS (2 vs $0-1$ ) and smoking habits (smoker vs never smoker). Only Kras mutation was statistically associated with PFS, with a favorable outcome ( $\mathrm{HR}=0.71,95 \% \mathrm{CI}: 0.53-0.96$; $\mathrm{p}=0.027$ ). A non-significant positive association was found

Table 3. Progression-free survival (PFS) of NSCLC patients according to individual characteristics

\begin{tabular}{|c|c|c|c|c|}
\hline & $\mathrm{N}$ & $\begin{array}{c}\text { Median PFS } \\
\text { (months) }\end{array}$ & $95 \% \mathrm{CI}$ & $\mathrm{p}$ \\
\hline Overall & 70 & 3.1 & $2.1-4.1$ & \\
\hline Age (years) & & & & 0.982 \\
\hline$\leq 61$ & 28 & 3.1 & $2.0-4.2$ & \\
\hline$>61$ & 42 & 2.5 & $1.1-3.9$ & \\
\hline Gender & & & & 0.043 \\
\hline Male & 48 & 2.2 & $1.0-3.4$ & \\
\hline Female & 22 & 4.6 & $1.4-7.8$ & \\
\hline Histology & & & & 0.562 \\
\hline Adenocarcinoma & 53 & 3.1 & $1.9-4.2$ & \\
\hline Squamous cell ca & 13 & 3.2 & $0.6-7.2$ & \\
\hline NSCLC unspecified & 4 & 1.6 & $0.1-1.8$ & \\
\hline \multicolumn{5}{|l|}{ PS ECOG } \\
\hline $0-1$ & 56 & 3.2 & $2.4-4.1$ & 0.137 \\
\hline 2 & 14 & 2.2 & $1.4-3.0$ & \\
\hline Smoking status & & & & 0.011 \\
\hline Never smoker & 11 & 5.8 & $1.1-10.5$ & \\
\hline Smoker & 59 & 2.2 & $1.1-3.3$ & \\
\hline EGFR genotype & & & & 0.020 \\
\hline Wild type & 55 & 2.4 & $1.3-3.4$ & \\
\hline Mutated & 15 & 4.6 & $2.7-6.5$ & \\
\hline Kras genotype & & & & 0.478 \\
\hline Wild type & 53 & 3.1 & $1.8-4.3$ & \\
\hline Mutated & 17 & 4.9 & $1.4-8.5$ & \\
\hline
\end{tabular}

for EGFR mutation ( $\mathrm{HR}=0.69,95 \% \mathrm{CI}: 0.47-1.02 ; \mathrm{p}=0.06)$ (data not shown).

Overall survival. During the study period, 67 patients $(95.7 \%)$ died. For the whole group, median survival time was 6.6 months (95\% CI: 4.7-8.4 months). OS at 6 and 12 months was $21 \%$ and $11 \%$, respectively. Survival of patients according to the various prognostic factors is shown in Table 4. In univariate analysis, a statistically significant association with survival was found for gender and smoke. Females survived longer than males ( 11.1 versus 5.0 months, $\mathrm{p}=0.002$ ) and never smokers survived longer compared to smokers (11.1 months vs 6.5 months, $\mathrm{p}=0.02$ ). Patients with stable disease or response survived 9.6 months compared to 4.0 months of those undergoing progression $(\mathrm{p}<0.001)$. Median OS was 5.1 months in mutated EGFR vs 6.8 months in wild type patients (Figure 3A, $\mathrm{p}=0.5$ ) and 8.3 months in mutated Kras vs 5.1 months in wild

\section{A}

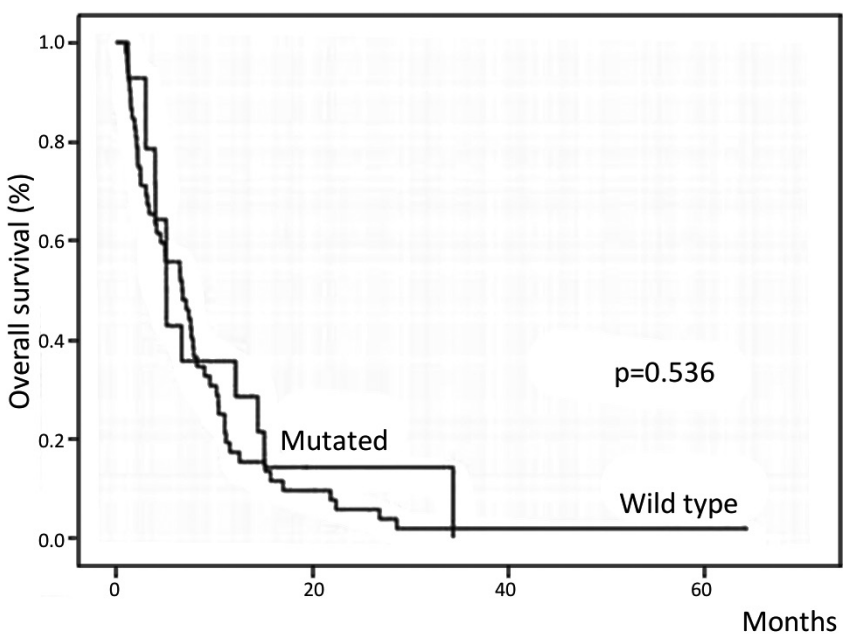

B

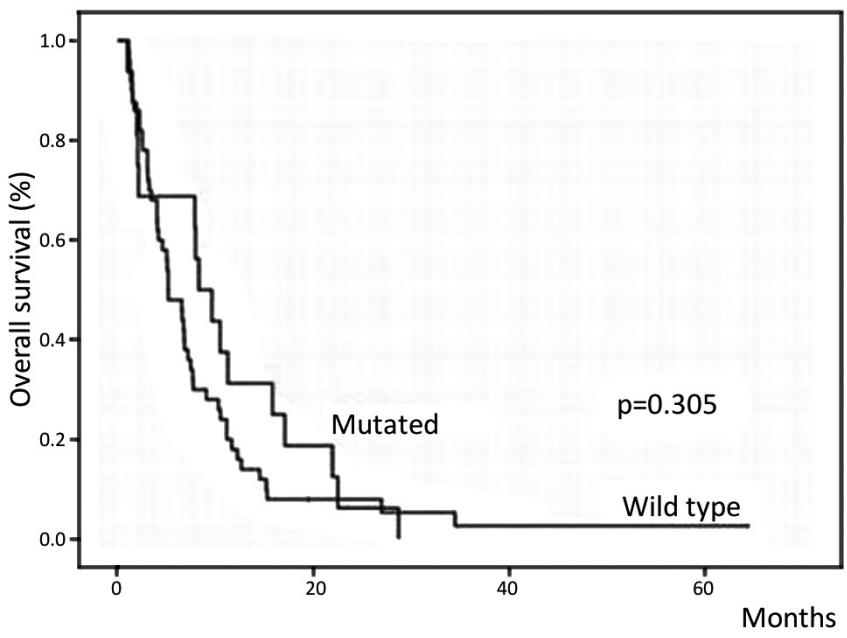

Figure 3. Overall survival of NSCLC patients according to EGFR (A) and Kras (B) 
Table 4. Overall survival (OS) of NSCLC patients according to individual characteristics

\begin{tabular}{|c|c|c|c|c|}
\hline & $\mathrm{N}$ & $\begin{array}{l}\text { Median survival } \\
\text { (months) }\end{array}$ & $95 \% \mathrm{CI}$ & $\mathrm{P}$ \\
\hline Overall & 70 & 6.6 & $4.7-8.4$ & \\
\hline Age (years) & & & & 0.925 \\
\hline$\leq 61$ & 28 & 6.8 & $0.5-13.1$ & \\
\hline$>61$ & 42 & 6.6 & $4.6-8.6$ & \\
\hline Gender & & & & 0.002 \\
\hline Male & 48 & 5.0 & $2.4-7.6$ & \\
\hline Female & 22 & 11.1 & $9.2-13.0$ & \\
\hline Histology & & & & 0.824 \\
\hline Adenocarcinoma & 53 & 6.5 & $4.5-8.6$ & \\
\hline Others & 13 & 6.7 & $2.8-10.6$ & \\
\hline NSCLC unspecified & 4 & 3.4 & $0.2-4.3$ & \\
\hline PS ECOG & & & & 0.204 \\
\hline $0-1$ & 56 & 6.8 & $5.7-7.9$ & \\
\hline 2 & 14 & 2.2 & $0.5-5.1$ & \\
\hline Smoking status & & & & 0.019 \\
\hline Never smoker & 11 & 11.1 & $3.5-18.7$ & \\
\hline Smoker & 59 & 6.5 & $4.7-8.4$ & \\
\hline Best response & & & & $<0.001$ \\
\hline Progression & 40 & 4.0 & $2.9-5.1$ & \\
\hline Stable dis/response & 30 & 9.6 & $6.2-13.0$ & \\
\hline EGFR genotype & & & & 0.536 \\
\hline Wild type & 55 & 6.8 & $3.9-9.6$ & \\
\hline Mutated & 15 & 5.1 & $3.7-6.5$ & \\
\hline Kras genotype & & & & 0.305 \\
\hline Wild type & 53 & 5.1 & $3.3-6.9$ & \\
\hline Mutated & 17 & 8.3 & 5.0-11.5 & \\
\hline
\end{tabular}

type patients (Figure 3B, $\mathrm{p}=0.3$ ). Median OS was 5.0 months (95\% CI: 2.1-8.0 months) in patients with both Kras and EGFR wild type tumors. According to the EGFR genotypes, the patient with mutated exon 18 survived 15.1 months. Median OS was 5.2 months (95\% CI: 0.5-25.0 months) in the patients with mutated exon 19 and 5.1 months (95\%CI: 2.4-7.8 months) in mutated exon 20 cases. The patient with mutation in exon 21 and the case of mutation of both exon 20 and 21 survived 1.3 months and 4 months, respectively. Multivariate analysis for OS included EGFR and Kras status (mutant vs wild type), gender (female vs male), PS (2 vs $0-1$ ) and smoke (smoker vs never smoker). In this case, female gender and Kras mutation confirmed to be favorable prognostic factors, but without reaching the significance (HR= $0.74,95 \% \mathrm{CI}: 0.53-1.03$, $\mathrm{p}=0.07$ and HR $=0.74,95 \%$ CI: $0.54-1.02 ; \mathrm{p}=0.066$, respectively). No influence on survival was observed with regard PS or EGFR mutation (HR=1.24, 95\% CI: $0.90-1.71 ; \mathrm{p}=0.2$ and $\mathrm{HR}=1.03$, $95 \%$ CI: 0.73-1.46; $\mathrm{p}=0.8$, respectively) (data not shown).

\section{Discussion}

In the present study we evaluated the role of EGFR and Kras on response to TKIs therapy, progression-free survival and overall survival in NSCLC patients undergoing second or third line therapy with EGFR-tyrosine kinase inhibitors and not included in clinical trials. Multivariate analysis showed only a tendency towards a positive association between EGFR and PFS. There was a non significant trend towards benefit for response and survival from Kras mutations, although Kras mutation had a significant positive impact on PFS.

The EGFR signaling pathway may be pivotal in the progression of NSCLC. Molecular targeted therapy based on EGFR-TKIs have become a treatment option after first-line chemotherapy in subgroups of patients with advanced NSCLC and mutations in EGFR and in other genes such as Kras [1,14], nevertheless the topic is still debated. In a first line setting, it has been shown that the EGFR-TKIs treatment has improved response, PFS and quality of life in patients harboring specific EGFR mutations [15-19]. Data from a meta-analysis quantifying the magnitude of benefit with upfront EGFR-TKIs showed a pooled hazard ratio of 0.45 (95\%CI: 0.36-0.58) for PFS and of 2.08 (95\%CI: 1.75-2.46) for overall response in EGFR mutation positive patients over chemotherapy [20]. Nevertheless, smoking history should be considered, since smoking was associated with shorter PFS after EGFR-TKIs treatment in advanced NSCLC patients with EGFR mutations [21]. The impact of EGFR status on survival is debatable, especially in patients treated beyond first-line therapy [3,16,22-27]. The effect on progression, as well as on OS could be limited to adenocarcinoma histotype [17]. Recent meta-analyses showed that EGFR-TKIs treatment prolonged PFS in EGFR mutation positive patients in all settings, with an HR of 0.43 (95\% CI: 0.38-0.49) for front-line, of 0.34 (95\% CI: $0.20-0.60)$ for second-line and of 0.15 (95\% CI: 0.08-0.27) for maintenance therapy. Nevertheless, EGFR-TKIs did not seem to have impact on OS [19], while the probability of obtaining a response increased in patients with EGFR mutation, in female or smokers patients who had never smoked (28). In contrast to the positive results, it is however possible that patients acquire resistance during a first- or second generation oral EGFR TKI, also after an initial response [29].

The role of Kras mutations remains to be clearly elucidated, mainly because of the small samples size of the studies and of the low prevalence of Kras mutations [2,11]. In contrast with our data, Kras mutations have been associated with EGFRTKI resistance [30], while no influence or a low response rate was found in some studies in second- and third-line settings $[25,31,32]$.

It remains unclear whether there is an association between Kras mutation and progression-free and overall survival $[2,17]$. According to some studies, Kras status impacts negatively survival $[22,26,27,31]$. In addition, Kras mutant patients experienced a significantly shorter PFS compared with those carrying a wild genotype [33,34]. A meta-analysis on 11470 NSCLC patients from 22 studies showed a higher frequency of Kras mutations among smokers than among never smokers (25\% versus $6 \%$ ) and among adenocarcinomas compared to 
other histologies (26\% versus $16 \%$ ). Kras mutations were associated with a lack of response to TKIs therapy. The objective response rate was $3 \%$ and $26 \%$ in mutation positive patients and in patients with wild-type genotype, respectively. The pooled relative risk for the objective response rate was 0.29 (95\% CI: 0.18-0.47). In spite of these results, it has been argued that the selection of patients on the basis of Kras status for EGFR-TKIs sensitivity in NSCLC patients has a limited value because of a mutually exclusive relationship between Kras and EGFR mutation and the lack of difference in survival between Kras mutant/EGFR wild-type and Kras wild-type/EGFR wildtype NSCLC [7].

In our series we found an EGFR and Kras mutation in 21\% and $24 \%$ of patients, respectively. Published data show a large variation of mutations in tumor samples, ranging between $7 \%$ and $45 \%$ for EGFR $[26,35,36]$ and between $7 \%$ and $23 \%$ for Kras $[25,26]$. In Western countries, a higher percentage of Kras mutations (30-50\%) was found in adenocarcinomas with respect to the other histotypes, while the mutation rate of EGFR tended to be low (3\% to 12\%) [37,38]. We did not find differences among histotypes with regard EGFR status, while Kras mutations were found only among adenocarcinomas. Consistently with literature, EGFR mutations were more frequent in never smokers, while Kras mutations were present only in smokers $[7,36,38]$.

Finally, our data of these second-third line setting patients not participating to any clinical trial showed a trend toward benefit for disease progression in patients with mutated EGFR Moreover, in our patients mutation of Kras oncogene was correlated to better PFS, in contrast with most of the other studies. The conflicting results regarding the role of Kras mutations on treatment response and patient outcomes have been recently attributed to a great molecular heterogeneity in tumors with mutated Kras, It is has been shown that disease stage at the time of diagnosis, specific Kras codon mutation and co-occurring genomic alterations may identify subgroups of mutant NSCLC with distinct biology and efficacy of targeted therapies $[39,40]$.

In our opinion, these discrepancies between our findings and those reported in the scientific literature are mostly due to the small number of patients and do not reflect real differences between patients enrolled in clinical studies and our "daily practice" patients. Given the burden of lung cancer, more confirmative results on the actual role of EGFR and Kras in NSCLC therapy are needed.

Acknowledgements: To Antonella Lacamera, Antonio Messina and Ornella Gallone, Villa Scassi Hospital, for data collection.

\section{References}

[1] HIRSCH FR, JANNE PA, EBERHARDT WE, CAPPUZZO F, THATCHER $\mathrm{N}$ et al. Epidermal growth factor receptor inhibition in lung cancer: status 2012. J Thorac Oncol 2013; 8: 373-384. https://doi.org/10.1097/JTO.0b013e31827ed0ff
[2] ROBERTS PJ, STINCHCOMBE TE, DER CJ, SOCINSKI MA. Personalized medicine in non-small-cell lung cancer: is KRAS a useful marker in selecting patients for epidermal growth factor receptor-targeted therapy? J Clin Oncol 2010; 28: 4769-4777. https://doi.org/10.1200/JCO.2009.27.4365

[3] JACKMAN DM, MILLER VA, CIOFFREDI LA, YEAP BY, JÄNNE PA et al. Impact of epidermal growth factor receptor and KRAS mutations on clinical outcomes in previously untreated non-small cell lung cancer patients: results of an online tumor registry of clinical trials. Clin Cancer Res 2009: 15: 5267-5273. https://doi.org/10.1158/1078-0432.CCR-09$\underline{0888}$

[4] NORMANDO SR, CRUZ FM, DEL GIGLIO A. Cumulative meta-analysis of epidermal growth factor receptor-tyrosine kinase inhibitors as first-line therapy in metastatic non-smallcell lung cancer. Anticancer Drugs 2015; 26: 995-1003. https:// doi.org/10.1097/CAD.0000000000000268

[5] INOUE Y, INUI N, ASADA K, KARAYAMA M, MATSUDA $\mathrm{H}$ et al. Phase II study of erlotinib in elderly patients with non-small cell lung cancer harboring epidermal growth factor receptor mutations. Cancer Chemother Pharmacol 2015; 76: 155-161. https://doi.org/10.1007/s00280-015-2784-X

[6] LEE CK, WU YL, DING PN, LORD SJ, INOUE A et al. Impact of Specific Epidermal Growth Factor Receptor (EGFR) Mutations and Clinical Characteristics on Outcomes After Treatment With EGFR Tyrosine Kinase Inhibitors Versus Chemotherapy in EGFR-Mutant Lung Cancer: A MetaAnalysis. J Clin Oncol 2015; 33: 1958-1965. https://doi. org/10.1200/JCO.2014.58.1736

[7] MAO C, QIU LX, LIAO RY. KRAS mutations and resistance to EGFR-TKIs treatment in patients with non-small cell lung cancer: a meta-analysis of 22 studies. Lung Cancer 2010; 69: 272-278. https://doi.org/10.1016/j.lungcan.2009.11.020

[8] LORIOT Y, MORDANT P, DEUTSCH E, OLAUSSEN KA, SORIA JC. Are RAS mutations predictive markers of resistance to standard chemotherapy? Nat Rev Clin Oncol 2009; 6: 528-534. https://doi.org/10.1038/nrclinonc.2009.106

[9] YING M, ZHU X, CHEN K, SHA Z, CHEN L. Should KRAS mutation still be used as a routine predictor of response to EGFR-TKIs in advanced non-small-cell lung cancer? A revaluation based on meta-analysis. J Cancer Res Clin Oncol 2015; 141: 1427-1439. https://doi.org/10.1007/s00432-015$\underline{1910-9}$

[10] NAIDOO J, DRILON A. KRAS-Mutant Lung Cancers in the Era of Targeted Therapy. Adv Exp Med Biol 2016; 893: 155-178. https://doi.org/10.1007/978-3-319-24223-1 8

[11] RIELY GJ, MARKS J, PAO W. KRAS mutations in non-small cell lung cancer. Proc Am Thorac Soc 2009; 6: 201-205. https:// doi.org/10.1513/pats.200809-107LC

[12] KHAMBATA-FORD S, HARBISON CT, HART LL, AWAD M, XU LA et al. Analysis of Potential Predictive Markers of Cetuximab Benefit in BMS099, a Phase III Study of Cetuximab and First-Line Taxane/Carboplatin in Advanced Non-SmallCell Lung Cancer. J Clin Oncol 2010; 28: 918-927. https://doi. org/10.1200/JCO.2009.25.2890

[13] EISENHAUER EA, THERASSE P, BOGAERTS J, SCHWARTZ LH, SARGENT D et al. New response evaluation criteria 
in solid tumours: revised RECIST guideline (version 1.1). Eur J Cancer 2009; 45: 228-247. https://doi.org/10.1016/j. ejca.2008.10.026

[14] ALIMUJIANG S, ZHANG T, HAN ZG, YUAN SF, WANG $Q$ et al. , Epidermal growth factor receptor tyrosine kinase inhibitor versus placebo as maintenance therapy for advanced non- small-cell lung cancer: a meta-analysis of randomized controlled trials. Pac J Cancer Prev 2013; 14: 2413-2419. https://doi.org/10.7314/APJCP.2013.14.4.2413

[15] FIALA O, PESEK M, FINEK J, KREJCI J, BORTLICEK $Z$ et al. Second line treatment in advanced non-small cell lung cancer (NSCLC): comparison of efficacy of erlotinib and chemotherapy. Neoplasma 2013; 60: 129-134. https://doi. org/10.4149/neo $2013 \quad 017$

[16] Gao G, Ren S, Li A, Xu J, Xu Q et al. Epidermal growth factor receptor-tyrosine kinase inhibitor therapy is effective as first-line treatment of advanced non-small-cell lung cancer with mutated EGFR: A meta-analysis from six phase III randomized controlled trials. Int J Cancer 2012; 131: E822-829. https://doi.org/10.1002/ijc.27396

[17] Pesek M, Benesova L, Belsanova B, Mukensnabl P, BRUHA F et al. Dominance of EGFR and insignificant KRAS mutations in prediction of tyrosine-kinase therapy for NSCLC patients stratified by tumor subtype and smoking status. Anticancer Res 2009; 29: 2767-2773.

[18] DOUILLARD JY, SHEPHERD FA, HIRSH V, MOK T, SOCINSKI MA et al. Molecular predictors of outcome with gefitinib and docetaxel in previously treated non-small-cell lung cancer: data from the randomized phase III INTEREST trial. J Clin Oncol 2010; 28: 744-752. https://doi.org/10.1200/ LCO.2009.24.3030

[19] LEE CK, BROWN C, GRALLA RJ, HIRSH V, THONGPRASERT $S$ et al. Impact of EGFR inhibitor in non-small cell lung cancer on progression-free and overall survival: a metaanalysis. J Natl Cancer Inst 2013; 105: 595-605. https://doi. org/10.1093/jnci/djt072

[20] BRIA E, MILELLA M, CUPPONE F, NOVELLO S, CERIBELLI A et al. Outcome of advanced NSCLC patients harboring sensitizing EGFR mutations randomized to EGFR tyrosine kinase inhibitors or chemotherapy as first-line treatment: a meta-analysis. Ann Oncol 2011; 22: 2277-2285. https://doi. org/10.1093/annonc/mdq742

[21] ZHANG Y, KANG S, FANG W, HONG S, LIANG W et al. Impact of smoking status on EGFR-TKI efficacy for advanced non-small-cell lung cancer in EGFR mutants: a meta-analysis. Clin Lung Cancer 2015; 16: 144-151. https://doi.org/10.1016/j. cllc.2014.09.008

[22] CADRANEL J, MAUGUEN A, FALLER M, ZALCMAN G, BUISINE MP et al. Impact of systematic EGFR and KRAS mutation evaluation on progression-free survival and overall survival in patients with advanced non-small-cell lung cancer treated by erlotinib in a French prospective cohort (ERMETIC project-part 2). J Thorac Oncol 2012; 7: 1490-1502. https:// doi.org/10.1097/JTO.0b013e318265b2b5

[23] MILELLA M, NUZZO C, BRIA E, SPERDUTI I, VISCA $P$ et al. EGFR molecular profiling in advanced NSCLC: a prospective phase II study in molecularly/clinically selected patients pretreated with chemotherapy. J Thorac Oncol 2012; 7: 672-680. https://doi.org/10.1097/ JTO.0b013e31824a8bde

[24] SCHNEIDER CP, HEIGENER D, SCHOTT-VON-ROMER K, GUTZ S, LAACK E et al. Epidermal growth factor receptor-related tumor markers and clinical outcomes with erlotinib in non-small cell lung cancer: an analysis of patients from german centers in the TRUST study. J Thorac Oncol 2008; 3: 1446-1453. https://doi.org/10.1097/ ITO.0b013e31818ddcaa

[25] KALIKAKI A, KOUTSOPOULOS A, HATZIDAKI D, TRYPAKI M, KONTOPODIS E et al. Clinical outcome of patients with non-small cell lung cancer receiving front-line chemotherapy according to EGFR and K-RAS mutation status. Lung Cancer 2010; 69: 110-115. https://doi.org/10.1016/j. lungcan.2009.09.010

[26] FIALA O, PESEK M, FINEK J, BENESOVA L, BORTLICEK $\mathrm{Z}$ et al. Gene mutations in squamous cell NSCLC: insignificance of EGFR, KRAS and PIK3CA mutations in prediction of EGFR-TKI treatment efficacy. Anticancer Res 2013: 33: 1705-1711. https://doi.org/10.1016/s0169-5002(13)70293-9

[27] LIM EH, ZHANG SL, LI JL, YAP WS, HOWE TC et al. Using whole genome amplification (WGA) of low-volume biopsies to assess the prognostic role of EGFR, KRAS, p53, and CMET mutations in advanced-stage non-small cell lung cancer (NSCLC). J Thorac Oncol 2009; 4: 12-21. https://doi. org/10.1097/JTO.0b013e3181913e28

[28] QI WX, FU S, ZHANG Q, GUO XM. Anti-epidermalgrowth-factor-receptor agents and complete responses in the treatment of advanced non-small-cell lung cancer: a metaanalysis of 17 phase III randomized controlled trials. Curr Med Res Opin 2015; 31: 25-33. https://doi.org/10.1185/030 $\underline{07995.2014 .978448}$

[29] SHEA M, COSTA DB, RANGACHARI D. Management of advanced non-small cell lung cancers with known mutations or rearrangements: latest evidence and treatment approaches. Ther Adv Respir Dis 2016; 10: 113-129. https:// doi.org/10.1177/1753465815617871

[30] TAKEDA M, OKAMOTO I, FUJITA Y, ARAO T, ITO H et al. De novo resistance to epidermal growth factor receptortyrosine kinase inhibitors in EGFR mutation-positive patients with non-small cell lung cancer. J Thorac Oncol 2010; 5: 399-400. https://doi.org/10.1097/JTO.0b013e3181cee47e

[31] GUAN JL, ZHONG WZ, AN SJ, YANG JJ, SU J et al. KRAS mutation in patients with lung cancer: a predictor for poor prognosis but not for EGFR-TKIs or chemotherapy. Ann Surg Oncol 2013; 20: 1381-1388. https://doi.org/10.1245/s10434$\underline{012-2754-Z}$

[32] PAO W, WANG TY, RIELY GJ, MILLER VA, PAN Q et al. KRAS mutations and primary resistance of lung adenocarcinomas to gefitinib or erlotinib. PLoS Med 2005; 2: e17. https:// doi.org/10.1371/journal.pmed.0020017

[33] METRO G, CHIARI R, DURANTI S, SIGGILLINO A, FISCHER MJ et al. Impact of specific mutant KRAS on clinical outcome of EGFR-TKI-treated advanced non-small cell lung cancer patients with an EGFR wild type genotype. 
Lung Cancer 2012; 78: 81-86. https://doi.org/10.1016/j. lungcan.2012.06.005

[34] LUDOVINI V, BIANCONI F, PISTOLA L, CHIARI R, MINOTTI V et al. Phosphoinositide-3-kinase catalytic alpha and KRAS mutations are important predictors of resistance to therapy with epidermal growth factor receptor tyrosine kinase inhibitors in patients with advanced non-small cell lung cancer. J Thorac Oncol 2011; 6: 707-715. https://doi. org/10.1097/JTO.0b013e31820a3a6b

[35] MURRAY S, KARAVASILIS V, BOBOS M, RAZIS E, PAPADOPOULOS S et al. Molecular predictors of response to tyrosine kinase inhibitors in patients with Non-Small-Cell Lung Cancer. J Exp Clin Cancer Res 2012; 31: 77. https://doi. org/10.1186/1756-9966-31-77

[36] Takamochi K, Oh S, Suzuki K. Differences in EGFR and KRAS mutation spectra in lung adenocarcinoma of never and heavy smokers. Oncol Lett 2013; 6: 1207-1212.

[37] WU CC, HSU HY, LIU HP, CHANG JW, CHEN YT et al. Reversed mutation rates of KRAS and EGFR genes in adeno- carcinoma of the lung in Taiwan and their implications. Cancer 2008; 113: 3199-3208. https://doi.org/10.1002/cncr.23925

[38] ESTEBAN E, MAJEM M, MARTINEZ AGUILLO M, MARTINEZ BANACLOCHA N, DOMINE M et al. Prevalence of EGFR mutations in newly diagnosed locally advanced or metastatic non-small cell lung cancer Spanish patients and its association with histological subtypes and clinical features: The Spanish REASON study. Cancer Epidemiol 2015; 39: 291-297. https://doi.org/10.1016/j.canep.2015.02.003

[39] WOOD K, HENSING T, MALIK R, SALGIA R. Prognostic and Predictive Value in Kras in Non-Small-Cell Lung Cancer: A Review. JAMA Oncol 2016; 2: 805-812 https://doi. org/10.1001/jamaoncol.2016.0405

[40] SKOULIDIS F, BYERS LA, DIAO L, PAPADIMITRAKOPOULOU VA, TONG P J et al. Co-occurring genomic alterations define major subsets of KRAS-mutant lung adenocarcinoma with distinct biology, immune profiles, and therapeutic vulnerabilities. Cancer Discov 2015; 5: 860-877 https://doi. org/10.1158/2159-8290.CD-14-1236 